\title{
AFGHANS AND ABORIGINES: DIYARI TEXTS
}

\author{
Ben Murray and Peter Austin
}

Ben Murray, the oldest and most fluent speaker of Diyari, now lives at Marree, South Australia, where he was born in 1891. His mother was Arabana and his father Afghan. Diyari was formerly spoken to the east of Lake Eyre in the far north of South Australia and currently has fewer than a dozen speakers. Ben Murray's two humorous stories about encounters with Afghans were told in Diyari to Peter Austin, who transcribes and analyses them here.

\section{Emily and the Afghans ${ }^{1}$}

The first story dates from Ben Murray's childhood in the late 1890 s. There were at that time a large group of Aboriginal people camped in the Frome Creek a few kilometres east of Marree and they were occasionally visited by some of the large number of Afghans who lived in Marree. The story concerns an encounter between Emily Russell (jirimimini), a cousin of Ben Murray, and two itinerant Afghans in the Frome Creek. It demonstrates one shrewd Aboriginal girl's handling of the Afghans' requests for sexual favours.

1. ngayani pirrki-rna
we plural excl-nom play -ptcple creek-loc there-loc
2. thana -li dika-yi nhinha Frome karidi.
they plural-erg calz-pres him-acc

1 The transcription employed here is a practical orthography and differs from that in Austin 1981. The digraphs $t h, n h$, th represent lamino-dental stop, nasal and lateral respectively, $j, n y$, $l y$ are lamino-palatals, $r h, r d, r m$, $r$ are apico-domals (retroflex), $r$ is a retroflex continuant, $r$ an apico-alveolar flap and $d$ between vowels is an apico-alveolar trill. Each numbered line is a sentence and commas separate clauses of complex sentences. The following abbreviations are used: abs - absolutive case; acc - accusative case; add - additional information; all allative case; antipass - antipassive; aux - auxiliary verb; dat - dative case; dist - distant; erg - ergative case; exclam - exclamation; fut - future tense; ident - identified information; imper - imperative mood; implDS - implicated (or purpose) clause whose subject is different from that of the main clause; imp1SS - implicated clause whose subject is the same as that of the main clause; inchoat - inchoative ('becoming'); loc - locative case; nom nominative case; old info - old information; pass - passive; pre - present tense; prop propietive ('having'); ptcple - participle; redup - reduplicated; reflex - reflexive; relDS - relative clause whose subject is different from that of the main clause; relSS - relative clause whose subject is the same as that of the main clause; trvb - transitive verbalizer; vicin - vicinity. For a description of the grammar of Diyari (phonology, morphology and syntax) see Austin 1981.

2. The distant past tense auxiliary wanthiyi is left out here since the context in which the story was told unambiguously located it in the distant past. 
ABORIGINAL HISTORY 1981 5:1

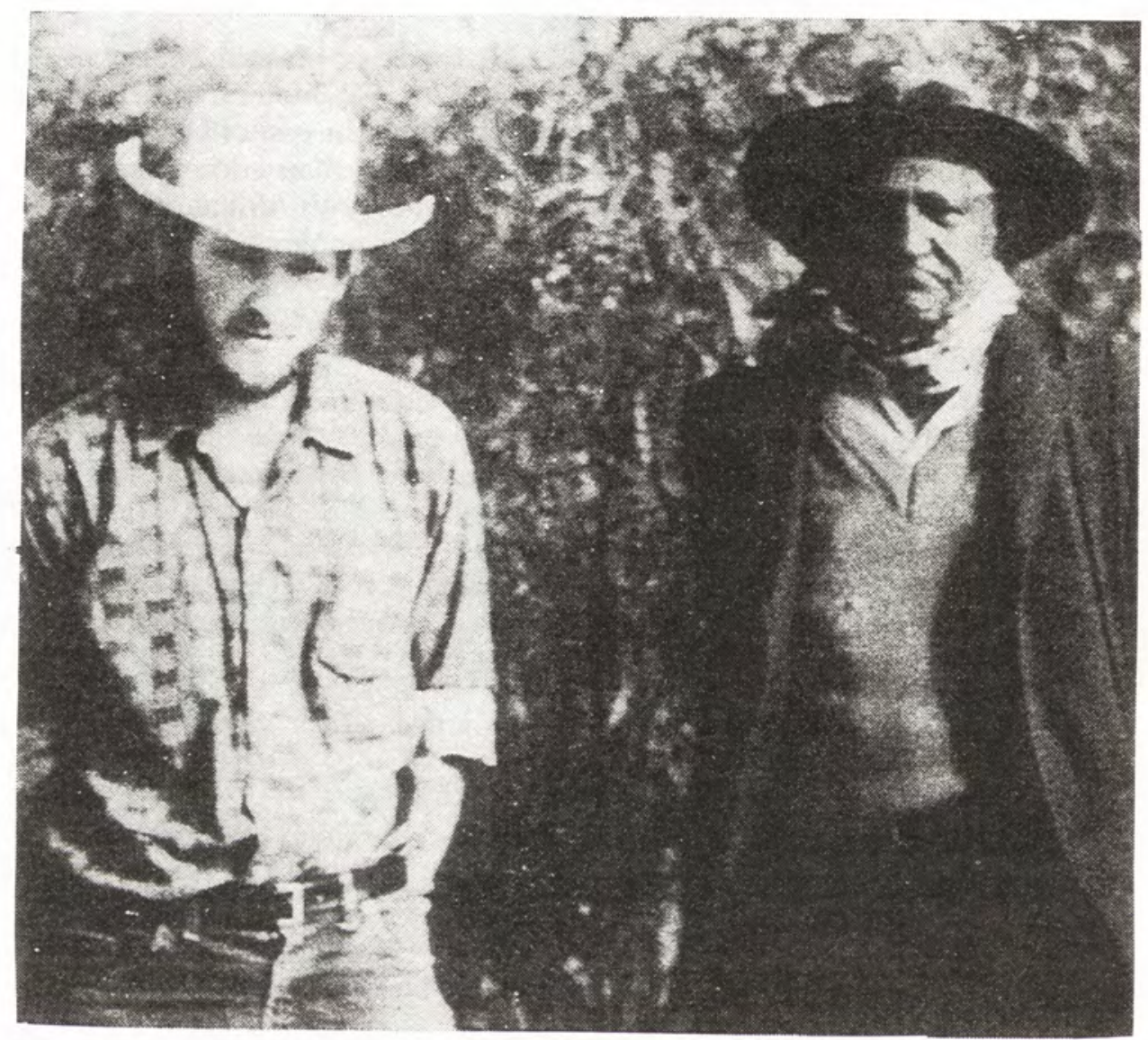

Peter Austin and Ben Murray, at Marree, S.A.

Photograph by LA. Hercus 


\section{AFGHANS AND ABORIGINES}

4. pula wakara-yi nhanthu-yali, thana they dual-nom come -pres horse -erg they plural-nom mankada pirrki-rnanhi pakarna karakara-lda-matha. girl-abs play -relDS also near -add-ident

5. pula kurlkunga-rna ngari -yi, nhanthu they dual-nom jump -ptcple go down-pres horse-abs kada-rna. tie -relsS

6. ngarda-nhi mankada parda-rna pada-yi then -loc girl-abs catch-ptcple lie -pres

7. Come on! Come on! Give me nikiniki'

8. nganha yingki-yamayi yani -ka. ${ }^{4}$ me-acc give -Imper like this-token

9. wapa-mayi: 5 go -imper

10. wapa-mayi yini! go -imper you

11. wata ngathu yinha nganja-yi. not I-erg you-acc want -pres

12. yini kini wanda nhanthu-yarri, you-nom penis-abs thick horse -like

dangki-danki -yarri. redup -donkey-like

13. yaru -ka nhani yatha-yi.

like that-token she-nom say -pres

14. yundu wata nganha kudaka -rnanhi nganhi yulya -nhi you-erg not me-acc rezease-relDS I-nom police-loc yatha-Iha nganayi. speak-fut aux

15. nganhi marlarlu yulya -nhi warrapa-thadi -lha nganayi. I-nom truly police-loc relate -antipass-fut aux

3 The origin of this word for sexual intercourse is unclear. The speech of the Afghans, as Ben Murray mimics it, shows a number of pidgin English features, e.g. [gIb] for 'give'; see also lines 16 and 24 of story 2.

4 This word was accompanied by an obscene hand gesture.

5 Lines 9-I6 were addressed to the Afghans in English and translated here into Diyari. 


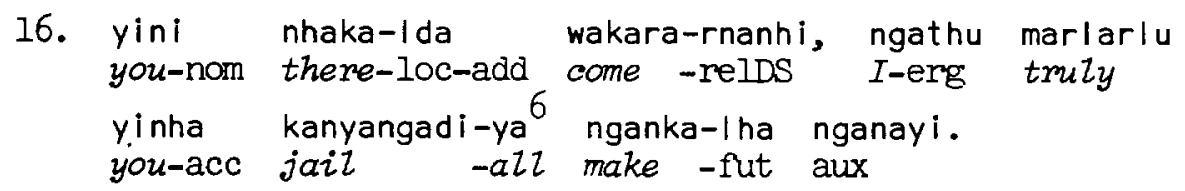

17. ngarda-nhi nhani karrka-yi.

then -loc she-nom shout-pres

18. kanku-wara -yi! nhawu -ya parla

boy -plural-exclam he-nom-near sexual arousal-erg

ngana-yi ngakangu.

be -pres me-loc

19. yarra wapa-ni -mayi, danga-danga -rna.

this way go -plumal-imper redup-hunt cavay-relsS

20. ngayani parrjarna mindi-yi.

we plural excl-nom alz-abs min -pres

21. ngarda-nhi pula -li thana -nha warrara-yi. then -loc they cual-erg them plural-acc leave -pres

22. nhanthu-nhi kathi-yi ngarda-nhi wapa-rna

- horse -loc climb-pres then -loc go -ptcple

kuda -rna, thuka-thadi-rna kuda -rna.

go away-relSS carry-pass-ptcple go away-relSS

23. yaru -ka thana murda-ya.

like that-token they plural-nom finish-past

24. ngarda-nhi nhani yatha-yi.

then -loc. she-nom say -pres

25. Yini nhaka-lda nhingki -rda wakara-rnanhi, you-nom there-loc-add here-vicin-loc come -relDS

nganhi madi -ya mindi-lha nganayi, yulya

I-nom Marree-all mun -fut aux police-abs

man i - I ha.

get -implSS

26. nganhi marlarlu ngunda-yi.

I-nom truly think-pres

27. kanji mindi-ya nhani, nhaka-lda nhawu

can run -past she-nom there-loc-add he-nom

wakara-rnanhi.

come-relds

6. The word kanyangadi is used for 'chain' and 'jail'; its pre-contact meaning is unknown. 


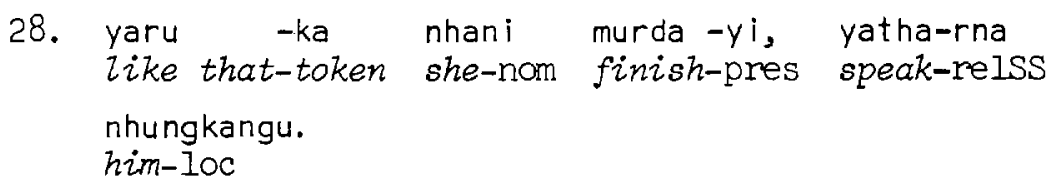

\section{Translation}

1. We were playing in the creek there.

2. They call it the Frome Creek.

3. Then two Afghans came up.

4. They came on horseback, right close to where the girls were playing.

5. They jumped down, tying the horses up.

6. They (one of them) grabbed (one of) the girls.

7. 'Come on! Come on! Give me nikiniki!

8. Give it to me like this'.

9. 'Go away!' (Emily said).

10. 'You go away!

11. I don't like you.

12. Your penis is big and thick like a horse, like a little donkey'.

13. That's what she said.

14. 'If you don't let me go I'll tell the police.

15. I'll truly tell the police all about it.

16. If you come again, I'll truly put you in jail'.

17. Then she called out.

18. 'Boys! He's sexually aroused over me.

19. Come over here and hunt (him) away'.

20. We all ran over.

21. Then they left them.

22. (They) climbed on their horses and went away, riding away.

23. That's how they finished.

24. Then she said.

25. 'If you come here again I'll run to Marree to get the police'.

26. I truly think.

27. She could have run (the distance) if he had come back again.

28. That's how she finished talking to him.

29. He never came back.

Dora and the Afghan

The second story is set at Etadunna on the Birdsville track when Ben Murray was a young man working on the station. It concerns Dora, a daughter of the European station manager, who used her knowledge of Diyari and of the Afghans' religious practices to make a public spectacle of an Afghan who stopped to talk to her. 
1. Dora nhani yatha-rna ${ }^{7}$ nhangkarni ngathata -nhi.
she-nom say -ptcple her-dat younger sibzing-loc

2. yula thika -lu -mayi.

you dual-nom retum-dual-imper

3. yurra ${ }^{8}$ wapa-ni -mayi, ngapiri ngandi-nhi you plural-nom go -plural-imper father mother-loc

yatha-Iha, nganha nhayi-rnanthu.

say -implss me-acc see -implDS

4. ngathu nhinha -ya ngari-lka-yi nganthi-nganthi-ya

I-erg him-acc-near go -trvb-pres redup -animal-all

nhingki-nhi-wa thana -nha wanda-lha nhinha

here -alz-dist them plural-acc show-implss him-acc

5. marlarlu ngarda-nhi pula thika-yi.

truly then -loc they dual-nom retum-pres

6. ayi! ngapiri! yarra wapa -lu, ngayana

well father this way go-dual-imper we plural incl-nom

nhayi-l ha Dora-nha.

see -implsS Dora-acc

7. Dora-ndu ngari - |ka-yi nganthi-nganthi-ya

Dora-erg go down-trvb-pres redup -animal-alz

nhingki-nhi-wa.

here -alz-dist

8. Dora-ndu ngari - lka-yi, mungka-mungka-rna nhinha

Dora-erg go down-trvb-pres redup-embrace-relss him-acc

yaru -ka, yaru -ka nguna kuda-rna

like that-token like that-token arm-abs put-relss

nhungkangu yarrkarla-nhi.9

him-loc neck -loc

9. ngalda wapa-yi nhingki-nhi-ya.

we dual incl-nom go -pres here -all-near

10. ngarda-nhi pula karakara ngana-yi marlarlu. then -loc they dual-nom close be -pres truly

11. [GRUNT! GRUNT!]

7. The distant past tense auxiliary wanthayi is here omitted. See note 2.

8 Line 4 is apparently an error as there were only two brothers involved (see line 5).

9 Dora put her arm around the Afghan's neck holding his head down so that he would not see where he was being led. 


\section{AFGHANS AND ABORIGINES}

12. yaru -ka piki-piki nhawu-pada. like that-token redup-pig he-nom-there

13. Oh he devil, this one!

14. nhawu kathi nhungkarni-li mangathanda he-nom clothing him-dat -erg head-abs

warlpa-thadi-rna, ngarda-nhi mindi-rna kuda -yi. cover-reflex-relsS then -loc $\mathrm{mm}$-ptcple go away-pres

15. mindi-rna kuda -yi, yatha-yatha-rna. run -ptcple go cway-pres redup-say -pres

16. He deviz! He devil!

17. mayi, minha-rri -yi yini? well what-inchoat-pres you-nom

18. nganha nhandu pardaka-rna warrayi, kuji me-acc she-erg take -ptcple aux deviz-abs wanda-I ha.

show -implSS

19. wata marla nhangkangu wapa-lha nganayi. not more her-loc go -fut aux

20. kuji nhandu -pada ngamalka-yi. deviz-abs she-erg-there have -pres

21. ngathu ngunda-rna.

I-erg think -ptcple

22. nhanhi mankada ngumu-yarri. she-nom girl good-like

23. ayi! kuji -nthu nhani! well deviz-prop she-nom

24. ngayani kingka-rnanhi, No Zaugh! No fun! we plural excl-nom laugh - relDS

25. wata kingka-ni -mayi. not laugh-plural-imper

26. kuji nhawu-pada. devil he-nom-there

$\begin{array}{lll}\text { 27. yurra } & \text { kuji } & \text { nhinha -pada thayi-yl. } \\ \text { you plural-nom devil-abs him-acc-there eat -pres }\end{array}$

28. yaru -ka nhawu yatha-yi.

like that-token he-nom say -pres 
29. yundu nganja-rna warrayi mankada.
you-erg want -ptcple aux girt-abs
30. yaru -ka nhandu yinha wanda-lha nganayi.
like that-token she-erg you-acc show-fut aux
31. wata marla ngathu nganja-yi, nhanha nhayi-lha.
not more I-erg want -pres her-acc see -implss

32. karlka-ni -mayi!

wait -plural-imper

33. ngathu nhinha ngari -lka -lha nganayi, nganthi-nganthi I-erg him-ace go down-trvb-fut aux redup -animal $\begin{array}{ll}\text { wanda-I ha } & \text { nhinha. } \\ \text { show-implsS him-acc }\end{array}$

34. wata nhandu piki dika-rna, windi yatha-rna not she-erg pig-abs name-ptcple oniy say -relss nganthi-nganthi. 10 redup -animal

35. marlarlu nhinha piki-ya nganka-rna nhandu truly him-acc pig-all snake-ptcple she-erg yakayitall pangki-nhi. gate side $-10 \mathrm{c}$

36. ngarda-nhi wanda-yi nhinha. then -loc show -pres him-acc

37. thana -pada yingkarni kamanali-tha. they plural-nom-there you-dat friend -ozd info

38. ngarda-nhi nhulu nhayi-yi. then -loc he-erg see -pres

39. ngarda nhawu yaru -ka kathi -yali then he-nom like that-token clothing-erg

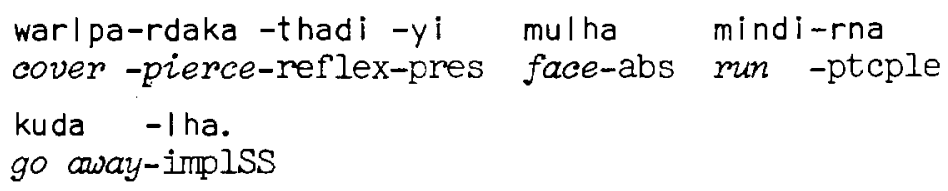

40. kuji nhawu-pada! kuji! devil he-nom-there devil

10. The Diyari word piki 'pig' is borrowed from English. Dora was careful not to say piki when speaking Diyari, lest the Afghan learn the purpose of her deception.

11 yakayita is borrowed from English 'gate', remolded to fit the pattern of Diyari words (words must be of at least two syllables and end in a vowel). 


\section{Translation}

1. She said to her brothers.

2. 'You two go back!'

3. 'You all go back to tell mother and father to watch me.

4. I will take him down there to the little animals, to show them to him'.

5. Then they went back.

6. 'Hey! Father! Come here and we will all watch Dora!'

7. Dora took him down there to the animals.

8. She took him down embracing him like this with her arm around his neck.

9. 'Let's go just down there', (she said).

10. Then they got really close.

11. [GRUNT! GRUNT!]

12. That was a pig (grunting) like that.

13. 'Oh, he devil this one!'

14. He ran away, covering his head with his turban.

15. He ran away, yelling out:

16. 'He devil! He devil!'

17. 'Hey, what happened to you?' (we asked him).

18. 'She took me down to show me the devil.

19. I won't go near her again.

20. She has devils.

21. I thought

22. She looked like a good girl.

23. No! She has devils!'

24. When we laughed (he said) 'No laugh! No fun!'

25. 'Don't laugh!

26. That's the devil.

27. You all eat those devils'.

28. That's what he said.

29. 'You wanted the girl.

30. And so she showed you'.

31. 'I don't want to ever see her again'.

32. 'Wait (she had said)

33. I'll take him down to show him the animals'.

34. She didn't say 'pig', only saying 'animals'.

35. Truly she took him to the pigs by the side of the gate.

36. Then she showed him.

37. 'These are your friends'.

38. Then he saw.

39. Then he covered his face with his turban like that and ran away.

40. He's the devil! Devil!

MARREE, SOUTH AUSTRALIA

and

LA TROBE UNIVERSITY

\section{BIBLIOGRAPHY}

Austin, P.K. A grammar of Diyari South Australia Cambridge, 1981. 